\title{
Quality of drinking water in rural areas: problems of legal environment
}

\author{
Volodymyr Yermolenko $^{1}$, Olena Hafurova ${ }^{1}$, Maryna Deineha ${ }^{1}$, Tamara Novak $^{1,{ }^{*}}$, Alena Temnikova ${ }^{2}$, and \\ Erdene Naidansuren ${ }^{3}$ \\ ${ }^{1}$ National University of Life and Environmental Sciences of Ukraine, 15 Heroiv Oborony Str., Kyiv, 03041, Ukraine \\ ${ }^{2}$ Pure Earth, 475 Riverside Drive, Suite 860, New York, NY 10115, United States of America \\ ${ }^{3}$ Environment and Security Center of Mongolia, NGO Suite \#123, Government House III, Baga Toiruu, 44 SB District, \\ Ulaanbaatar, Mongolia
}

\begin{abstract}
The article is devoted to the scientific and theoretical analysis of the current state of legal provision of drinking water quality in rural areas. It was stated that in recent years there has been a steady trend of deteriorating quality of water used for drinking in rural areas, including due to increasing levels of nitrate pollution. Proposals have been made for: further implementation of Council Directive 98/83 / EU on the quality of water intended for human consumption and Council Directive 91/676/ EEC on the protection of waters against pollution caused by nitrates from agricultural sources in national legislation; elimination of substantive inconsistencies between State sanitary norms and rules 2.2.4-171-10 "Hygienic requirements for drinking water intended for human consumption" and National Standards of Ukraine 7525: 2014 "Drinking water. Requirements and methods of quality control "in terms of drinking water quality indicators; inclusion in the subjects of state water monitoring of the central executive body that implements the state policy in the field of health care (regarding the monitoring of drinking water); development of the Procedure for state monitoring of nitrate content in surface and groundwater as a component of state water monitoring; forecasting at the level of the National Target Program "Drinking Water of Ukraine" for 2021-2025 "development and operation of a single state information resource - Interactive map of drinking water quality in Ukraine.
\end{abstract}

\section{Introduction}

Currently, one of the urgent problems facing Ukraine is to provide the population with drinking water of proper quality and in sufficient quantities. Our country already has a water shortage, ranking 111th in the world out of 152 in terms of available water resources [1]. From year to year, there is a process not only of reducing water supplies in general, but also the rapid deterioration of its quality characteristics, which makes it impossible to use such water for human consumption or has a very negative impact on public health. There are many reasons for this, including intensive pollution of water sources with wastewater and other industrial emissions, and unsatisfactory condition of water mains, aging and wear of water treatment systems, and weakening of state control over the state of drinking water sources, and so on.

The situation is especially difficult in rural areas, where only $32.3 \%$ of residential buildings are equipped with centralized water supply [2, p. 222], and most residents of villages and settlements use drinking water from wells, wells, catchments of springs. Published official data (the latest - as of 2019) on the state of sources and systems of drinking water supply in rural areas clearly illustrate the existing problems in terms of providing drinking water to the rural population of Ukraine (Fig. 1 and Fig. 2) [3, p. 71].

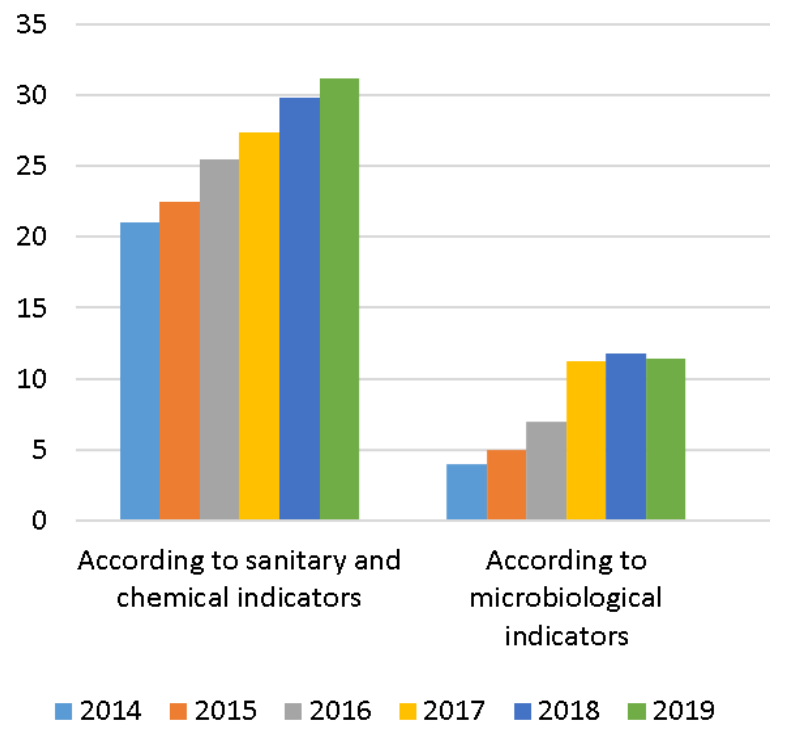

Fig. 1. Proportion of non-standard drinking water samples taken from rural centralized water supply sources, $\%$.

\footnotetext{
* Corresponding author: tomanovak1980@gmail.com
} 
The problem of contamination of drinking water sources in rural areas with nitrates should be singled out, as agricultural activity is the main cause of this type of pollution, and drinking water with excessive content of these substances is potentially dangerous for all, and especially harmful for children, provoking water-nitrate methemoglobinemia, other diseases.

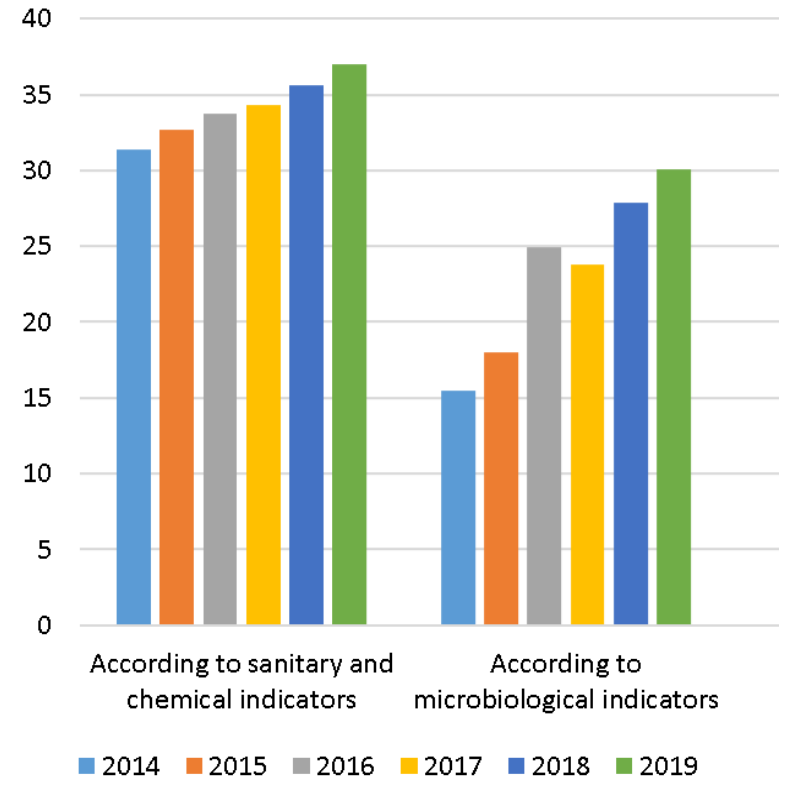

Fig. 2. The proportion of non-standard samples of drinking water taken from mine wells, $\%$.

Data on monitoring the content of nitrates in water for 2016-2019 are shown in Fig. 3 [3, p. 73].
According to statistics, the number of registered cases of nitrate poisoning is growing: if in 2018 there were three, in 2019 there were already seven cases of nitrate poisoning, non-communicable disease of water-nitrate methemoglobinemia (in Zhytomyr, Poltava, Kharkiv and Chernihiv regions) [3, p. 74]. From the given data the wide geography of distribution of nitrate pollution of sources of drinking water supply is visible.

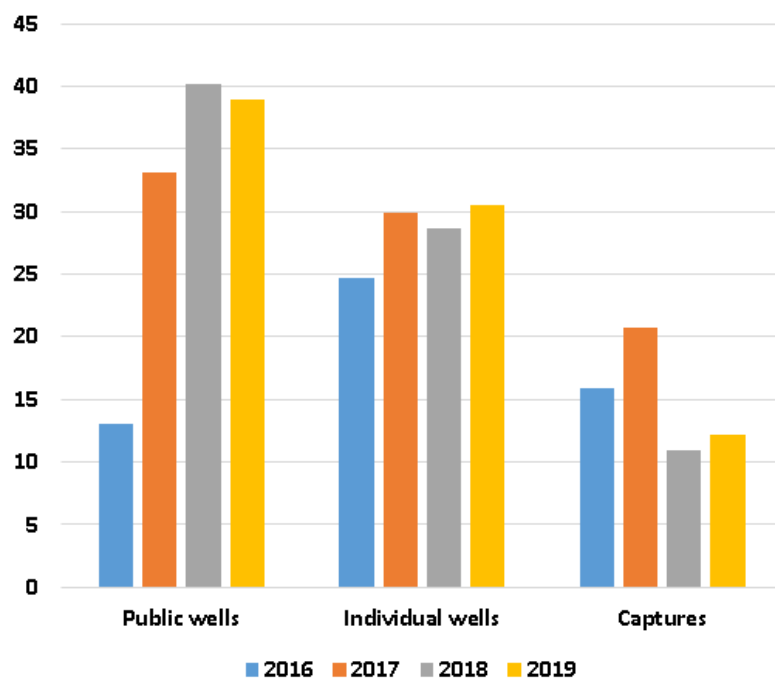

Fig. 3. The proportion of drinking water samples taken from rural decentralized sources of drinking water supply that do not meet the requirements for nitrate content, $\%$.

Data on the average content of nitrates in artesian and groundwater in different regions of Ukraine are shown in Fig. 4.

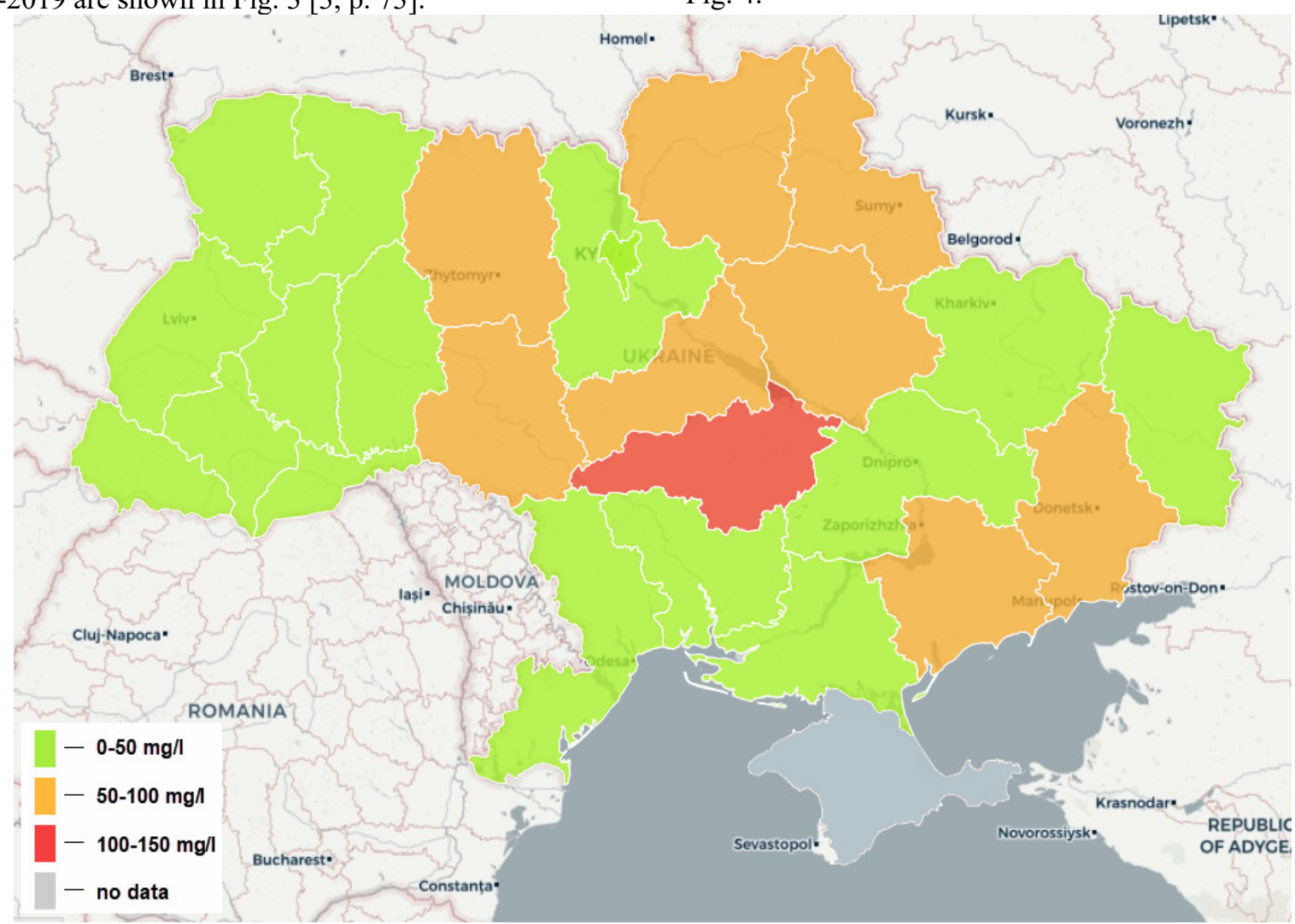

Fig. 4. Average nitrate content in artesian and groundwater in different regions of Ukraine (according to: https://waternet.ua/quality_map). 
Along with the above, in 9 regions of Ukraine (Dnipropetrovsk, Donetsk, Zaporizhia, Ivano-Frankivsk, Kirovohrad, Mykolaiv, Odesa, Poltava and Kherson) imported water is used for drinking [4].

One of the ways to improve drinking water supply in rural areas should be clear and effective legal regulation. And the basis for developing an effective mechanism for providing the rural population of Ukraine with quality drinking water should be: establishing criteria for drinking water quality and regulation at the regulatory level of monitoring in the field of drinking water and drinking water supply in rural areas to determine relevant data on drinking water sources. The study of these issues and the formulation of relevant proposals is the purpose of this article.

\section{Results}

According to the international (Article 4 of Council Directive $98 / 83 / \mathrm{EU}$ on the quality of water intended for human consumption [5]) and domestic (Article 1 of the Law of Ukraine "On Drinking Water, Drinking Water Supply and Sewerage" of 10.01.2002) legislation, drinking water is considered safe and clean if it meets the established requirements for organoleptic, microbiological, parasitological, chemical, physical and radiation parameters. These indicators are regulated: firstly, at the international level - in Annex I, parts A and B of Council Directive 98/83/EC, and secondly, at the national level. Ukraine has State sanitary norms and rules 2.2.4-171-10 "Hygienic requirements for drinking water intended for human consumption", approved by the order of the Ministry of Health of Ukraine dated 12.05.2010 № 400 and National Standards of Ukraine 7525: 2014 «Drinking water. Requirements and methods of quality control" [6].

As the generalization of the results of existing scientific research shows, the above-mentioned State sanitary norms and rules 2.2.4-171-10 and National Standards of Ukraine 7525: 2014 do not fully take into account international standards for drinking water, although the Implementation of Council Directive 98/83/EU Articles 360-363, 365, 366, Annex XXX of the Association Agreement between Ukraine, of the one part, and the European Union, the European Atomic Energy Community and their Member States, of the other part (hereinafter referred to as the Association Agreement) [7], and the introduction to the National Standards of Ukraine 7525: 2014 explicitly states the implementation of the basic requirements of Council Directive 98/83 /EU.

As rightly noted by O.S. Pronevych State sanitary norms and rules 2.2.4-171-10 in terms of fixed indicators of drinking water quality are generally correlated with Council Directive 98/83/EU, but the domestic document differentiates the requirements for tap water, water from wells (catchments of springs) and packaged water, in contrast to Council Directive 98/83/EU, which sets uniform general requirements for indicators of drinking water quality and safety. In our opinion, the approach enshrined at the international level is more correct, as the basic minimum requirements for drinking water quality should be the same regardless of the source of such resources. Differentiated (for sources of centralized and decentralized drinking water supply), it is advisable to set additional requirements or expand the list of indicators of quality and safety of water intended for human consumption. Another significant drawback: the establishment of State sanitary norms and rules 2.2.4-17110 permissible levels in drinking water from wells and catchments of nitrite sources (not more than $3.3 \mathrm{mg} / \mathrm{l}$ ), while Council Directive 98/83 / EC allowed the content of these substances is not more than $0.50 \mathrm{mg} / 1$ [8, p. 183]. Note that the National Standards of Ukraine 7525: 2014 sets the standard for nitrite content in water of decentralized drinking water supply at a level not exceeding $0.02 \mathrm{mg} / 1$. Another significant difference between State sanitary norms and rules 2.2.4-171-10 and Council Directive 98/83 / EU - domestic sanitary rules, in contrast to the international standard, do not provide for control of the content of benzopyrene, bromate, cyanide in drinking water, epichlorohydrin, tetrachlorethylene and trichlorethylene, vinyl chloride. At the same time, National Standards of Ukraine 7525: 2014 sets permissible standards for all these substances, except epichlorohydrin and vinyl chloride.

In addition, between the National Standards of Ukraine 7525: 2014 and State sanitary norms and rules 2.2.4-171-10 there are other inconsistencies in terms of epidemic safety indicators, the maximum allowable content of chemical and toxicological indicators $[9, \mathrm{p}$. 401]. In order to eliminate such conflicts, in our opinion, it is first necessary to bring State sanitary norms and rules 2.2.4-171-10 in line with Council Directive 98/83 / EU in terms of drinking water quality indicators, and the next step should be to bring National Standards of Ukraine 7525: 2014 in accordance with State sanitary norms and rules 2.2.4-171-10. This follows from the fact that the State sanitary norms and rules 2.2.4-171-10 are binding on the executive authorities, local governments, enterprises, institutions, organizations, regardless of ownership and subordination, whose activities are related. with the design, construction and operation of drinking water supply systems, production and circulation of drinking water, supervision and control in the field of drinking water supply, and citizens. This provision is enshrined both in the State sanitary norms and rules 2.2.4171-10 (paragraph 1.1 of the Section "General Provisions") and in the basic Law of Ukraine "On drinking water, drinking water supply and drainage" (Articles 9, 23, 28, 38, 39, etc.). As for the National Standards of Ukraine 7525: 2014, at present in accordance with Art. 4 of the Law of Ukraine "On Standardization" of 05.06.2014, national standards are applied voluntarily, unless otherwise provided by regulations. The instruction on the recommended nature of application is contained in the National Standards of Ukraine 7525: 2014 (item 1.2). In addition, the Law of Ukraine "On Amendments to Certain Legislative Acts of Ukraine in Connection with the Adoption of the Law of Ukraine" On Standardization "of September 20, 2019 in the text of the Law of Ukraine" On Drinking Water, Drinking Water Supply and Sewerage " and "standard" in all cases is replaced by the words "state sanitary norms and rules", thus putting an 
end to the question of the type of document that sets requirements for drinking water quality.

The next aspect we would like to focus on is the legal regulation of monitoring the quality of drinking water in rural areas. Currently, the Law of Ukraine "On Drinking Water, Drinking Water Supply and Sewerage" provides in Art. 39 state monitoring in the field of drinking water and drinking water supply, determines the entities authorized to implement this measure and delimits their competence. However, in fact, monitoring in the field of drinking water and drinking water supply is carried out within the framework of state water monitoring. We will note that in 2018 for replacement of the Order of implementation of the state monitoring of waters (approved by the resolution of the Cabinet of Ministers of Ukraine from 07/20/1996 № 815), the resolution of the Cabinet of Ministers of Ukraine from 09/19/2018 № 758 the Procedure for implementation of the state monitoring of waters was approved. This document corresponds to Annex XXX to Chapter "Environment" of Chapter V "Economic and Sectoral Cooperation" of the Association Agreement, and to Directive 2000/60 / EU of the European Parliament and of the Council of 23.10.2000 establishing a framework for Community action in the field of water policy [10]. According to experts, the new procedure eliminates duplication of functions between different subjects of monitoring, provides a clear procedure and systematic approach to monitoring the status of terrestrial, groundwater, marine waters, expands the list of biological, hydromorphological, chemical and physicochemical indicators for monitoring [11].

Considering the provisions of the current Procedure for state water monitoring through the prism of monitoring in the field of drinking water supply, we consider as a shortcoming the lack of a list of subjects of state water monitoring of the central executive body implementing state health policy. Thus, in the previous Procedure for state water monitoring, monitoring of sanitary norms of chemical, bacteriological and radiological indicators of water bodies used for drinking purposes was entrusted to the State Sanitary and Epidemiological Service of Ukraine, which until 2017 was part of the executive branch. in the field of health care and ensured the implementation of state policy in the field of sanitary and epidemiological well-being of the population. The consequence of such institutional transformations has been a significant reduction in the material, technical and human resources of laboratories engaged in the analysis of water quality indicators. This, in turn, led to a decrease (compared to 2014) in the number of samples from mine wells (2.6 times) and from catchments of springs (1.5 times) [12], and we have already indicated that it is decentralized sources drinking water supply is essential for providing rural settlements with drinking water. Given all the above, we support the existing proposals on the need to separate from the structure of the State Service of Ukraine for Food Safety and Consumer Protection of the State Sanitary and Epidemiological Service of Ukraine and propose to include this body in the state monitoring of water (for drinking water).
Also important for determining the state of drinking water sources in rural areas is the issue of monitoring the nitrate content in surface and groundwater. The obligation to carry out such monitoring is provided by Council Directive 91/676/EEC of 12 December 1991 on the protection of waters against pollution caused by nitrates from agricultural sources [13].

Implementation of the Nitrate Monitoring Program in Surface and Groundwater for Ukraine is provided for in Annex XXX to Ch. 6 of the Association Agreement and included in the Action Plan for the implementation of the Association Agreement between Ukraine, on the one hand, and the European Union, the European Atomic Energy Community and their Member States, on the other hand, approved by the Cabinet of Ministers of 25.10.2017 № 1106. However, despite the expiration of these tasks on 31.12.2020, they remain unfulfilled at present. So far, only draft documents have been developed that indirectly affect the protection of water resources from nitrate pollution from agricultural sources. These are the draft Methodology for identifying areas vulnerable to nitrate compounds and the draft Code of Best Agricultural Practices [14]. Accordingly, no work is being done to identify nitrate-vulnerable areas; creation of their register, as well as monitoring of nitrate content in surface and groundwater [15, p. 46].

As noted in Art. 39 of the Law of Ukraine "On Drinking Water, Drinking Water Supply and Sewerage" the purpose of state monitoring in the field of drinking water and drinking water supply is "collection, processing, storage and analysis of information on drinking water quality, status of centralized drinking water supply, forecasting its changes and development of scientifically substantiated recommendations for making appropriate decisions in this area". In turn, one of the principles of state policy in the field of drinking water, drinking water supply and drainage of Art. 6 of the same law calls for free access to information on the quality of drinking water, the state of sources and systems of drinking water supply and drainage, and in Art. 9 - every consumer of drinking water is guaranteed the right to free access to information on drinking water quality. To do this: 1) the central executive body that implements state policy in the field of housing and communal services prepares and publishes the annual National Report on drinking water quality and drinking water supply in Ukraine (according to the Procedure approved by the Cabinet of Ministers of Ukraine from 29.04.2004 № 576); 2) provides interested public authorities, public organizations, enterprises, institutions, organizations and citizens with information on cases and causes of drinking water pollution. These provisions correlate with international requirements - Art. 13 and other Council Directives 98/83/EU and directly relate to the realization of the human right to drinking water.

We would like to note that the human right to drinking water is recognized in the world as one of the fundamental rights. Thus, UN General Assembly Resolution № 64/292 of 28 July 2010 and the comments of the UN Committee on Economic, Social and Cultural Rights № 15 of 2002 defines the right to drinking water and adequate sanitation as a mandatory component of the fundamental human 
right to life and health [16]. Another document, the UN Declaration on the Rights of Peasants and Other Persons Working in Rural Areas, identifies the right to safe and clean drinking water and sanitation for this category of people as fundamental to a full life, the exercise of all human rights and human dignity. 17]. To ensure this right, as K.D. Yanishevska and A.D. Skoryk absolutely rightly prove, it is necessary to ensure the connection between the right to information, primarily environmental, and proper management, public participation in decision-making by public administration bodies [18, pp. 701].

In our opinion, the above methods of informing the population about the quality of drinking water through the publication of the annual report and in case of pollution of drinking water do not fully guarantee compliance with the right to information about the state of drinking water. For example, the National Report on Drinking Water Quality and the State of Drinking Water Supply in Ukraine in 2019 has been published so far, ie we have official information a year ago, so to speak, in retrospect. Prompt informing the population about the current state of drinking water quality is very limited, and available resources vary in the amount of information and presentation. For example, the website of Kyivvodokanal constantly updates microbiological and physico-chemical indicators of drinking water quality control at control points of the distribution water supply network of Kyiv [19]. The website of Ternopilvodokanal contains average microbiological and sanitary-chemical indicators of drinking water quality as of the third quarter of 2020 [20]. There are also data on the quality of drinking water in some observation points (water intakes) (Fig. 5). With regard to rural settlements, there are no such resources in free access at all.

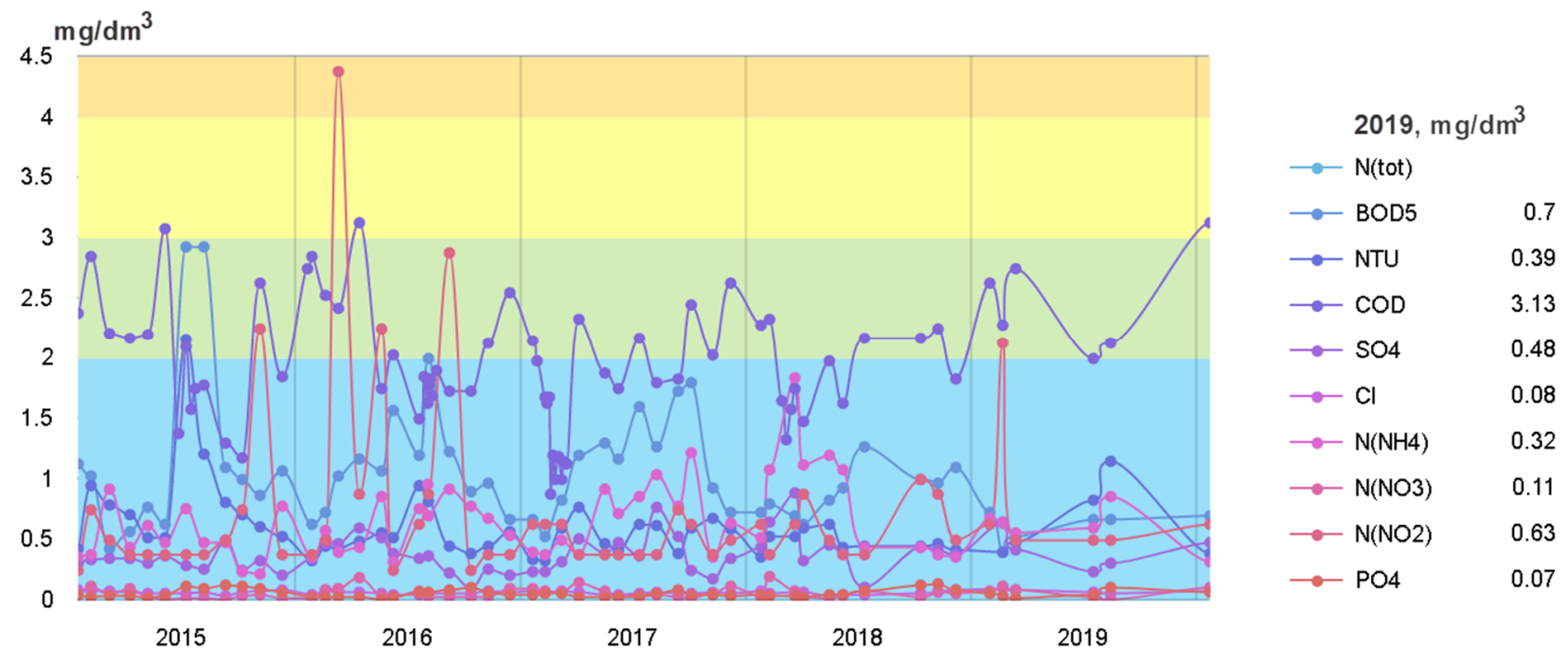

Fig. 5. Data on water quality (water intake of Kyiv). Full name of the observation point: Dnipro, 897 km, Vyshhorod, Kyiv HPS, drinking water intake, Kyiv (according to http://openenvironment.org.ua/).

Instead, commercial structures propose the development of a very important and promising tool for local communities to accumulate data on the state of drinking water sources, influence those responsible for the provision of water supply services and plan measures to improve drinking water quality, drinking water supply, protection of sources and systems, drinking water supply, restoration of drinking water supplies - interactive maps of drinking water quality [21]. However, these initiatives remain unpopular in practice due to limited local budgets. Hence, we propose to include in the National Target Program "Drinking Water of Ukraine for 2021-2025", the project of which is currently being developed [22] as a separate measure to develop an interactive map of drinking water quality in Ukraine and providing funding.

\section{Conclusions}

Thus, the priority measures to improve the legal regulation of providing the rural population of our country with quality and safe drinking water should be the following. Continue work on the implementation of Council Directive $98 / 83 / \mathrm{EU}$ on the quality of water intended for human consumption into national law. Elimination of substantive inconsistencies between State sanitary norms and rules 2.2.4-171-10 "Hygienic requirements for drinking water intended for human consumption" and National Standards of Ukraine 7525: 2014 "Drinking water. Requirements and methods of quality control "in terms of drinking water quality indicators. Inclusion in the subjects of state water monitoring of the central executive body that implements the state policy in the field of health care (for drinking water monitoring) and development of the Procedure for state monitoring of nitrate content in surface and groundwater as part of state water monitoring. Provision at the level of the National Target Program "Drinking Water of Ukraine for 2021-2025" to develop and ensure the functioning of a single state information resource Interactive map of drinking water quality in Ukraine.

\section{References}

1. S. Stasiuk, V. Maidanovych The problem of drinking water in Ukraine (2020), https://aw-therm. com.ua/problema-pitnoyi-vodi-v-ukrayini/ 
2. Statistical collection "Regions of Ukraine" (2019). 309.

3. National report on drinking water quality and the state of drinking water supply in Ukraine in 2019 (Ministry of Development of Communities and Territories of Ukraine, 2020), https://www.minregion.gov.ua/napryamkidiyalnosti/zhkh/teplo-vodopostachannya-tavodovidvedennya/natsionalna-dopovid/naczionalnadopovid-pro-yakist-pytnoyi-vody-ta-stan-pytnogovodopostachannya-v-ukrayini-za-2019-rik/

4. On the state and measures to provide drinking water to the population of Ukraine (2020), https://www.minregion.gov.ua/press/news/pro-stanta-zahody-po-zabezpechennyu-pytnoyu-vodoyunaselennya-ukrayiny-rozyasnennya-minregionu/.

5. On the quality of water intended for human consumption: Council Directive 98/83/EU of 3 November 1998, http://zakon.rada.gov.ua/laws/ show/994_963/ed20170208.

6. National Standards of Ukraine 7525:2014 "Drinking water. Requirements and methods of quality control" (The publication is official. K., 2015)

7. Annex XXX to Chapter 6 "Environment" of the Association Agreement between Ukraine, of the one part, and the European Union, the European Atomic Energy Community and their Member States, of the other part. https://eu-ua.org/tekst-uhodyproasotsiatsiiu/dodatky-rozdil-

v/navkolyshniepryrodne-seredovyshche

8. O.S. Pronevych, Implementation of European standards for drinking water quality: institutional and legal aspect. Law Forum 3, 182-189 (2017)

9. V.V. Zaitsev, N.I. Rublevskaya, O.A. Shevchenko, V.V. Koval, The need for phased implementation of National Standards of Ukraine 7525: 2014 "Drinking water. Requirements and methods of quality control". Collection of scientific works of workmates P.L. Shupik National Medical Academy of Postgraduate Education 24(5), 398-404 (2015)

10. On establishing a framework for Community action in the field of water policy: Directive 2000/60 / EU of the European Parliament and of the Council of 23.10.2000, http://zakon5.rada. gov.ua/laws/show/994_962

11. The European order of water monitoring has started to work in Ukraine, https://mepr.gov.ua/news/33011.html

12. Brief report on the progress of the implementation of the Protocol on Water and Health in Ukraine in 20162018, https://mepr.gov.ua/news/33428.html

13. On the protection of waters against pollution caused by nitrates from agricultural sources: Council Directive 91/676/EEC of 12 December 1991, https://www.kmu.gov.ua/storage/app/ sites/1/55GOEEI/direkӨva-radi-91-676-ees. pdf

14. The Government has intensified work on the implementation of the Nitrates Directive, http://ecoprostir.com/2020/07/21/v-uryadiaktyvizuvaly-robotu-nad-vprovadzhennyamnitratnoyi-dyrektyvy/

15. O.V. Hafurova, Problems of improving Ukrainian legislation in the sphere of drinking water quality (on the example of implementation of the nitrate directive). Law. Human. Environment 11(3), 41-49 (2020). doi.org/10.31548/law2020.03.005

16. Resolution of the UN General Assembly № 64/292 of 28.07.2010, http://daccess-ddsny.un.org/doc/UNDOC/GEN/N09/479/37/PDF/N09 47937.pdf? OpenElement

17. Draft United Nations Declaration on the Rights of Peasants and Others Working in Rural Areas, http://www.ohchr.org/Documents/ HRBodies/HRCouncil/WGPleasants/ Session5/A_HRC_WG.15_5_3-Russian.pdf

18. K.D. Yanishevskaya, A.D. Skoryk, The right to drinking water as an axiom in human rights. Young Scientist. 10(62), 699-702, (2018)

19. Indicators of drinking water quality control in control points of the distribution water supply network of Kyiv, https://vodokanal.kiev.ua/yak\%D1\%96st-vodi

20. Water quality III quarter 2020, http://www.vodokanal.te.ua/pro-nas/technichnaharakteristika/yakist-vodi/item/1993-yakist-vody-ivkvartal-2020-3-roku

21. M1MT: Interactive map of drinking water quality, https://magneticonemt.com/m1 gis-interaktivnakarta-yakosti-pitnoyi-vodi/

22. On approval of the Concept of the National target program "Drinking water of Ukraine" for 2021-2025 ": draft order of the Cabinet of Ministers of Ukraine. http://spo.fpsu.org.ua/na-obgovorenni-v-spo/6335proekt-rozporyadzhennya-kmu-pro-skhvalennyakontseptsiji-zagalnoderzhavnoji-tsilovoji-programipitna-voda-ukrajini-na-2021-2025-roki. 